\title{
Standing Repo Facilities, Then and Now
}

\section{Stephen Quinn}

Texas Christian University

\section{William Roberds}

Federal Reserve Bank of Atlanta

\section{Charles M. Kahn}

University of lllinois and

Visiting Scholar
CENTER FOR QUANTITATIVE

ECONOMIC RESEARCH

CENTER FOR HUMAN

CAPITAL STUDIES

CENTER FOR FINANCIAL INNOVATION AND STABILITY

CENTER FOR HOUSING

AND POLICY

\section{Summary:}

Recently there have been discussions, both within the FOMC and more broadly, about whether the FOMC should set up a standing repo facility. Such a facility would allow banks to sell safe assets (U.S. Treasury securities) to the Fed, with the assurance of subsequent repurchase, in unlimited quantities at an administered rate. This is not a new idea. In fact, a similar facility was implemented in 1683 by the Bank of Amsterdam, the leading central bank of the time, and operated for more than a century afterward. In this article, we describe the motivations, operations, and limitations of the Bank of Amsterdam's facility and what lessons this historical experience offers for modern-day central banks.

\section{Key findings:}

1. A standing facility can deepen markets for both collateral and reserves but can be vulnerable to large swings in its usage.

2. A central bank may wish to offset (or "sterilize") such swings and these offsets may increase the central bank's need to engage in other types of market operations.

3. In tail events, the scale of this sterilization can undermine a central bank's own credibility.

https://doi.org/10.29338/ph2020-01

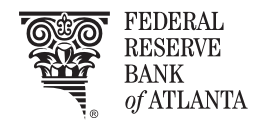

The Federal Reserve Bank of Atlanta's Policy Hub

leverages the expertise of Atlanta Fed economists and researchers to address issues of broad policy interest. Our research centers coordinate this work and seek to influence policy discussions. Areas of interest include: forecasting, fiscal policy, and macroeconomics (Center for Quantitative Economic Research); financial stability, innovation, and regulation (Center for Financial Innovation and Stability); human capital, labor markets, health, and education (Center for Human Capital Studies); and government-sponsored entity reform, mortgage markets, and affordable housing (Center for Housing and Policy). Sign up for email updates at frbatlanta. org/research/publications/policy-hub. 


\title{
Standing Repo Facilities, Then and Now*
}

\author{
Stephen Quinn, ${ }^{\dagger}$ William Roberds, ${ }^{\ddagger}$ and Charles M. Kahn ${ }^{\S}$
}

December 20, 2019

\begin{abstract}
Summary: Recently there have been discussions, both within the Federal Open Market Committee (FOMC) and more broadly about whether the FOMC should set up a standing repo facility. Such a facility would allow banks to sell safe assets (U.S. Treasury securities) to the Fed with the assurance of subsequent repurchase, in unlimited quantities at an administered rate. This is not a new idea. In fact, a similar facility was implemented in 1683 by the Bank of Amsterdam, the leading central bank of the time, and it operated for more than a century. Below, we describe the motivations, operations, and limitations of the Bank of Amsterdam's facility and what lessons this historical experience offers for modern-day central banks.
\end{abstract}

\section{Introduction}

A recent focus of Federal Reserve policy has been the liquidity of U.S. money markets. Responding to market fluctuations experienced during mid-September 2019, ${ }^{1}$ the Fed began daily overnight repurchase (repo) operations ${ }^{2}$ on September 17, 2019, followed by term repos to bridge the end of the third quarter. ${ }^{3}$ These actions were followed on October 11 by the Federal Open Market Committee's (FOMC) announcement of measures "to mitigate pressures that could adversely affect monetary policy implementation." Measures adopted by the FOMC include daily overnight repurchase (or repo) transactions, semiweekly term repos, and outright purchases. ${ }^{4}$ Outright purchase operations will be continued until banks' reserve levels reach at least their level of early September 2019. The

\footnotetext{
* Views expressed are those of the authors and not necessarily those of the Federal Reserve Bank of Atlanta or the Federal Reserve System. Helpful comments on earlier drafts were provided by Ed Nosal, Paula Tkac, Larry Wall, and Warren Weber. Emil Mihaylov provided research assistance. The authors also thank many Dutch colleagues for helpful instruction in the history of the early modern Netherlands. Special thanks are due to Joop Baneke and Taco Tichelaar for their guidance through the literature on the Crisis of 1763.

† Professor of Economics, Texas Christian University

$¥$ Research Economist and Adviser, Federal Reserve Bank of Atlanta

$\S$ Professor Emeritus of Finance, University of Illinois, and Visiting Scholar, Federal Reserve Bank of Atlanta

${ }^{1}$ On September 17, unusually high rates were observed in both the Treasury repurchase and fed funds markets (see figures 2 and 3 below). We discuss factors contributing to this volatility later in this article.

${ }^{2}$ A repurchase, or repo, transaction consists of the sale of an asset followed by a repurchase of the same asset. The seller of the asset in the first transaction is the buyer in the second. A repo resembles a collateralized loan, but the legal rights of the asset purchaser in the first transaction are stronger than that of a traditional lender, as noted below.

3 These repo operations and other Federal Reserve open market operations are recorded on the New York Fed's website at <www.newyorkfed.org/markets/op policies.html $>$ (accessed on January 9, 2020). See, in particular entries, for September 17, 2019, and September 20, 2019.

4 Outright or permanent open market operations occur when a central bank buys or sells assets in order to permanently increase or decrease central bank balances.

5 The initially announced size of these measures was $\$ 75$ billion minimum for overnight repos, $\$ 35$ billion for term repos, and outright purchases of $\$ 60$ billion. All purchases were of Treasury bills (Federal Open Market Committee 2019a, Federal Reserve Bank of New York 2019b). On December 12, 2019, the Federal Reserve Bank of New York announced that additional liquidity would be offered around yearend, including an expansion of overnight repos to $\$ 150$ billion and a term repo of up to $\$ 75$ billion (Federal Reserve Bank of New York 2019d).
} 
stated objective is to ensure "that control over the level of the federal funds rate and other short-term interest rates is exercised primarily through the setting of the Federal Reserve's administered rates." This is to be accomplished by supplying sufficient reserves so that "active management of the supply of reserves is not required” (Federal Open Market Committee 2019a).

There have also been discussions about an alternative approach to ensuring money market liquidity, which would involve the Fed setting up a standing repo facility. Rather than providing liquidity through a sequence of discretionary open market operations, a standing repo facility would allow banks to sell U.S. Treasury securities to the Fed, with the assurance of subsequent repurchase, in unlimited quantities at an administered rate. Earlier this year, David Andolfatto of the Federal Reserve Bank of St. Louis and Jane Ihrig of the Board of Governors created a proposal outlining the operation of such a facility (Andolfatto and Ihrig 2019a, b). They argue that a standing repo facility would enable tight control over short-term interest rates while reducing financial institutions' need for reserves. At their October 2019 meeting, the FOMC took up discussion of such a facility (Federal Open Market Committee 2019b).

Introducing a standing repo facility would be an evolutionary rather than revolutionary shift in the FOMC's policy framework. Other central banks currently make extensive use of standing facilities, ${ }^{6}$ and an unsuccessful proposal for a standing repo facility in the United States was floated in the 1950s (Garbade 2016). But the history of such facilities goes back much further. In fact, a standing repo facility was proposed in the seventeenth century for the leading central bank of the era, the Bank of Amsterdam ("the Bank"). The Bank adopted the proposal in 1683 and then operated this facility for more than a hundred years, providing an important source of liquidity to contemporary European financial markets. Some serious problems arose with the facility, however, which are discussed below.

Though the institutional details are different, some noteworthy parallels exist between this historic repo facility and facilities that have been proposed for the FOMC. Below, we describe the motivations, operations, and limitations of the Bank's facility and what lessons this historical experience offers for modern-day central banks. To preview our main conclusions, these are

1. A standing facility can deepen markets for both collateral and reserves, but it can be vulnerable to large swings in its usage.

2. A central bank might wish to offset (or "sterilize") such swings, and these offsets can increase the central bank's need to engage in other types of market operations.

3. In tail events, the scale of this sterilization can undermine a central bank's own credibility.

\section{The Bank of Amsterdam}

The Bank was founded in 1609 as an agency of the City of Amsterdam, and it remained in operation until 1820. By the time of the standing repo proposal (1677), approximately 2,000 Amsterdam merchants kept accounts at the Bank (Van Dillen 1925, 985). This group included the city's important merchant banks as well as other members of the merchant elite. ${ }^{7}$ Privileged (semi-) governmental entities such as the Dutch East India Company also kept accounts at the Bank. These parties used the Bank to facilitate payments among themselves to settle debts arising from commerce and finance.

\footnotetext{
${ }^{6}$ Perhaps the most prominent contemporary example is the European Central Bank's (ECB) Marginal Lending Facility. See, for example, Lee and Sarkar (2018) for a discussion of the ECB facility.

7 Typical for the time, Amsterdam's merchant banks dealt in goods as well as finance and were funded through market transactions rather than deposits. See Gelderblom, Jonker, and Kool (2016) on the market-oriented structure of contemporary Dutch finance.
} 
Nowadays, commercial bank demand for central bank reserves stems ultimately from their unique role at the center of the modern payments system. In seventeenth-century Amsterdam, merchants' balances at the Bank played a similar role: bills of exchange payable in Amsterdam were customarily discharged by transfer of merchants' balances on the books of the Bank. ${ }^{8}$ The Bank's money consisted entirely of deposits, and these made up essentially all of its liabilities. ${ }^{9}$

The Bank's money was backed by safe assets. Today when we think of "safe assets," we have in mind Treasury securities. In Amsterdam at the time, safe assets consisted instead of gold and silver, principally in the form of trade coins. ${ }^{10}$ At the time trade coins were flowing in great abundance into Amsterdam, but the flows could vary sharply over short time intervals, due for example to such factors as the arrival of silver fleets from Spain or the departure of the Dutch East India Company's expeditions to Asia, which were also heavily laden with silver. ${ }^{11}$

The early Bank used traditional methods to link trade coins and deposits. When a merchant deposited coins into the Bank, his account would be credited. ${ }^{12}$ He could withdraw his account balance from the Bank at will, in the form of trade coins, but withdrawal was subject to a steep transaction fee. The fees covered the Bank's operating expenses and eliminated potential arbitrage profits from people depositing coins and then withdrawing coins with slightly higher precious metal content. The fees also covered any minting costs incurred by the Bank (Van Dillen 1934, 1964d and Quinn and Roberds 2014). The fees also meant it was expensive for merchants to "park" coins at the Bank for short periods. As a result, all sorts of trade coins regularly came into the city, but deposits of such coins into the Bank were rare, even as these were constantly paid out by the Bank for shipment abroad (Quinn and Roberds 2014, 5-6).

The mismatch between merchants' willingness to deposit and withdraw meant that the stock of Bank balances was under contractionary pressure. To counter this pressure, the Bank routinely engaged in what we can consider as discretionary "outright" open market operations. ${ }^{13}$ These were most probably purchases of silver bullion (or perhaps of Spanish coin; archives are incomplete for this time period); the Bank then minted these silver purchases into Dutch trade coins, which it made available for withdrawal at the usual price. These silver purchases were made on an ad hoc basis, and it is probably best to think of them as intended to address a (long-term) goal of maintaining Bank balances above some target level.

In short, the early Bank enjoyed demand for its money but was limited by a highly frictional process of handling coins.

\footnotetext{
${ }^{8}$ Many bills payable in Amsterdam were made payable in Bank funds, meaning that discharge occurred through the Bank. However, some bills were made payable in "current money," and these were often discharged through private intermediaries known as "cashiers," who are described later in this article. Relatively few records survive of this second channel of settlement. Of the two settlement channels, settlement through the Bank seems to have predominated.

${ }^{9}$ Unlike modern central banks, the Bank of Amsterdam did not issue circulating currency.

${ }_{10}$ Trade coins were high-denomination coins used to transact with foreign markets, the most famous example being Spanish silver coins known as dollars or pieces of eight. Gorton (2017) defines a safe asset as one whose value is not subject to adverse selection. In the seventeenth century, gold and silver trade coins came closer to meeting this definition than any government security. Such coins flowed predominantly eastward, from American mines to Western Europe, thence on to Baltic, Mediterranean, and Asian locations (on these flows, see for example Attman 1986, Barrett 1990, or TePaske and Brown 2010).

${ }^{11}$ Under a 1647 treaty with Spain, the Dutch Republic was recognized as a "staple" (official market) for Spanish silver arriving from the New World (Van Dillen 1970, 31).

${ }^{12}$ Such deposits were limited primarily to trade coins, although minor amounts of small coins were sometimes accepted. Withdrawals were of trade coins.

${ }_{13}$ As occurs with modern central banks, the Bank implemented an open market purchase by crediting the asset seller's account for the amount of the purchase.
} 


\section{Costs of obtaining liquidity}

By 1677, as detailed by Amsterdam merchant Johannes Phoonsen, there was widespread dissatisfaction with the Bank's mode of operation. Three factors, all of which should have resonance with current readers, contributed to this dissatisfaction: an abundance of safe assets in the economy, a strong demand for central bank money, and the unpredictable cost of converting one of these assets into another. The first factor has already been discussed, here we consider the latter two.

Obligations to settle bills of exchange could arise swiftly and unpredictably. There was no clearinghouse or similar arrangement to net either these obligations or the payments that discharged them. Market discipline was extreme; failure to honor a bill could quickly lead to a merchant's loss of reputation and subsequent bankruptcy. Accordingly, precautionary demand for Bank balances was great, and merchants in Amsterdam could desire to convert quickly from safe assets to central bank balances. Still, the cost of conversion was volatile and could be high, depending on market conditions. The Bank had no discount window. The City of Amsterdam did operate a kind of lender-of last-resort or Lombard facility (the "Bank of Lending," essentially a municipal pawn brokerage). However, Phoonsen's discussion indicates that use of this facility carried some degree of stigma. ${ }^{14}{ }^{15}$

What alternatives were then available for a merchant in need of central bank funds on short notice?

- The most straightforward and reliable path to funding was to deposit coins in the Bank, but withdrawal fees were steep (1.5 percent or higher). Hence, a short-term deposit to meet a funding need was an expensive way to borrow.

- It was possible for merchants to borrow funds with silver or gold as collateral. But private lenders at the time lacked the bankruptcy "safe harbor" privilege that modern repo cash lenders enjoy. ${ }^{16}$ Full resolution of bankruptcies could last as long as 33 years. Although secured creditors were given priority and accelerated repayment in bankruptcy proceedings, repayment was not immediate and so secured loans were expensive (De Jong Keesing 1939, 124).

- Unsecured borrowing was also relatively expensive and could be volatile. Even for the most reputable merchants the implicit interest rate on bills of exchange averaged about 4 percent, and these were subject to risk of unwinding ("protest"), in which case a creditor might demand immediate payment (Flandreau et al. 2009b, 165).

- As an alternative to these channels, from about 1646 there arose a secondary market for Bank funds (Van Dillen 1964d, 367). Traders met daily in front of the Bank and exchanged Bank balances for "current money" (meaning all types of coins but also balances with private brokers, known as "cashiers"). Bid-ask spreads in this market were $1 / 8$ percent or less, making it an attractive way to acquire or dispose of Bank balances. Sale of a trade coin in the secondary

\footnotetext{
14 Stigma occurs when borrowers are reluctant to use a credit facility for fear of negative reputational consequences. See Carlson and Rose (2017) for a discussion of stigma as it applies to Fed discount window lending. Phoonsen did not use the word "stigma," but "disrespect" (Van Dillen 1921, 96).

15 Amsterdam's municipal Lombard, known as the Bank of Lending, was founded in 1614 as a public alternative to what were seen as usurious private pawnbrokers. Consistent with "pawnbroker stigma," most of the Bank of Lending's loans (69 percent as of 1678) were for relatively small sums, less than 100 guilders, as compared to a typical merchant's bill of exchange of ten times that amount or more (Dehing and 't Hart 1997, 45).

16 "Safe harbor" refers to exemption of a creditor's claim from bankruptcy stay. For discussions of the role of safe harbors in modern repo markets, see Garbade (2006) or Gorton and Metrick (2010).
} 
market, however, meant ceding control over potentially valuable collateral (specific types of trade coins were needed for transactions in certain foreign markets). Prices paid in the daily secondary market were recorded as the premium or agio on Bank balances relative to current money, and the agio could routinely fluctuate from 3 percent to $4 \frac{1}{2}$ percent or slightly higher.

\section{Phoonsen's proposal: Let merchants sell now, repurchase later}

Though Phoonsen's 1677 book contained many suggestions for improving the operations of the Bank, the most fundamental was his proposal that the Bank engage in secured lending against trade coin, at low interest rates, and that the Bank be granted a safe harbor privilege for such activity:

It should be allowed for everyone to pledge coins [to the Bank] ... at an interest of no more than onebalfpercent for a period of six months. This under the condition that these coins may be again removed from the Bank within six months or prolonged upon payment of interest; but after this interval has passed, the coins should become the absolute property of the Bank... (Phoonsen, quoted in Van Dillen 1921, 96).

Phoonsen argued that the facility's low interest rate would be appropriate in view of the high quality of its collateral:

And in fact, real [i.e., high-quality] silver and gold [coin] is an imperishable form of security, unless the coin itself should also perish ... (ibid., p. 98).

The proposal also addressed the issue of stigma, arguing that credit granted through this facility would be of a more virtuous character than credit available through the city's existing Lombard facility, so that in contrast "a merchant should suffer no disrespect" if he were to bring in desirable trade coins to the new facility (ibid, p. 96).

\section{Implementation}

The Bank implemented Phoonsen's proposal for a standing repo facility in 1683. Eligible silver trade coins could be sold to the Bank and repurchased within six months at an interest rate of $1 / 4$ percent (the interest rate for one favored Dutch coin, the zilveren rijder, was even lower: $1 / 8$ percent), and gold coins carried a six-month interest rate of $1 / 2$ percent (Van Dillen 1934, 102-103). The transactions could be rolled over at the same cost. In such transactions, the Bank purchased Dutch trade coins at official values and foreign trade coins at their estimated metallic value.

This proposal was implemented somewhat differently from modern repo facilities. In return for selling coin to the bank, the merchant received two assets: a credit on his bank account, and a receipt for the coin. The receipt entitled its holder to repurchase the coins sold ("redeem the receipt") at the sale price plus appropriate interest. In modern terminology, a receipt was an American call option on the coins sold, with a strike price equal to the sale price plus the interest rate, and an expiration date of six months after the sale. Receipts circulated outside the Bank as negotiable bearer instruments, and the associated trade coin collateral remained in the Bank's vaults until the receipt was redeemed. This arrangement saved on assay and bookkeeping costs. Figure 1 illustrates a stylized pair of transactions with the facility. 


\section{Figure 1}

\section{Schematic of the Bank's Standing Facility}

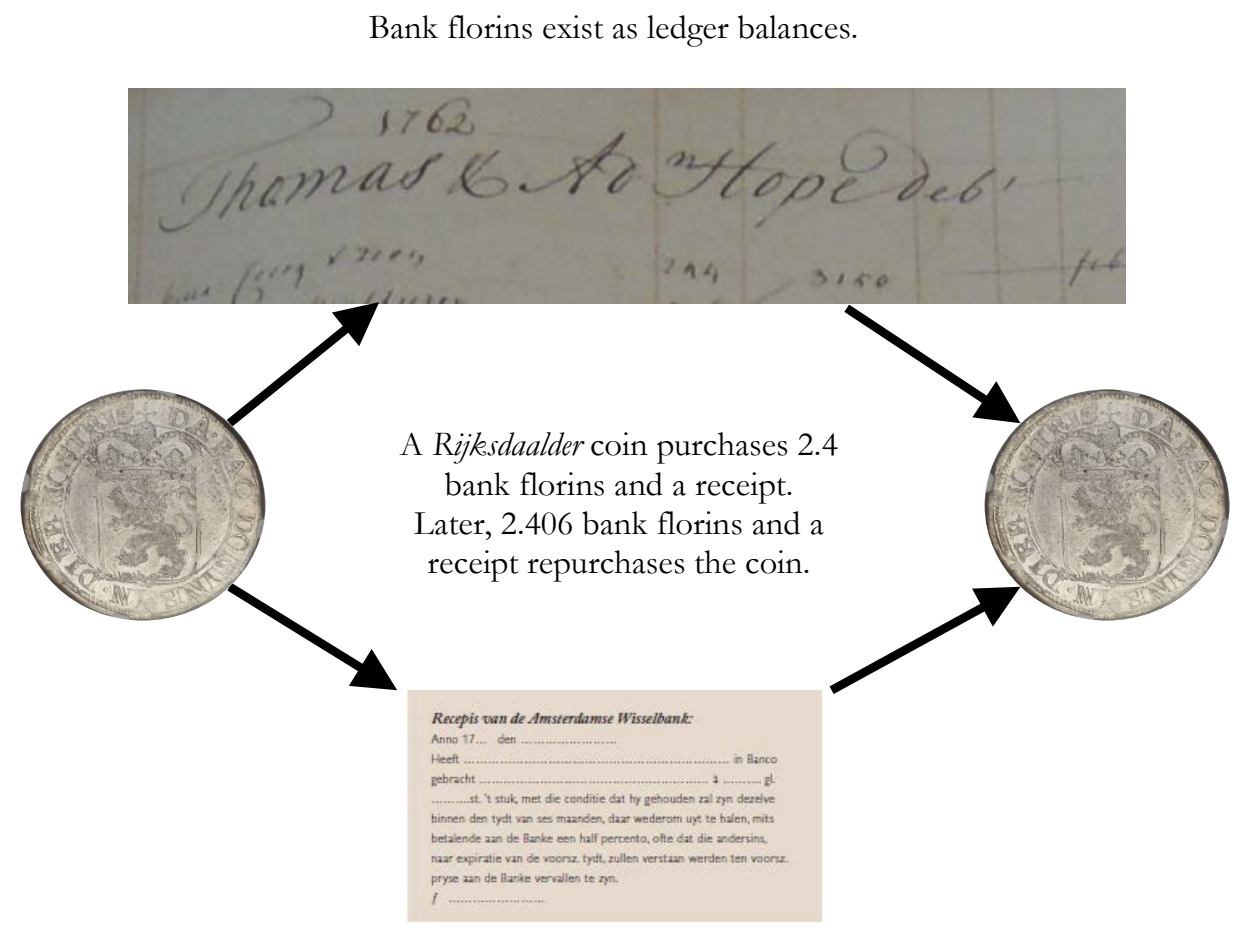

Receipts exist as circulating paper.

The option lasts six months and carries a fee of $1 / 4$ percent.

A merchant sells a Dutch coin known as a rijksdaalder ("rixdollar") to the Bank and repurchases it six months later. The value of the rijksdaalder outside the Bank is 2.5 guilders. The Bank, however, values the same coin at 2.4 "bank florins," a separate unit of account that was applied to Bank balances. At the sale, the merchant is credited with 2.4 bank florins to his account and receives a receipt for the rijksdaalder. Six months later, the same merchant presents the receipt to the Bank and is able to repurchase a rijksdaalder for 2.406 bank florins by transferring funds in his Bank account to the Bank's master account. 
Structuring the first leg of this arrangement as a sale and a second leg as an option apparently conferred a safe harbor privilege on the Bank. If a merchant failed to redeem a receipt, it was simply viewed as an expired option, and the Bank had unencumbered possession of the collateral. Private lenders did not enjoy the same privilege. ${ }^{17}$

For silver coins, the repurchase option was almost always redeemed, so this facility did in fact function as a term repo facility. Transactions with gold coins were more complex. For a variety of reasons, the Bank did not want to encourage transactions in gold, ${ }^{18}$ and so it penalized them with both a higher interest rate ( $1 / 2$ percent versus $1 / 4$ percent) and a larger "haircut." ${ }^{19}$ As a result the gold window was lightly used, and oftentimes the redemption option was not exercised, in which case the coin was said to "fall to" the Bank.

The Bank's new facility was extremely popular. Essentially, it enabled merchants for the first time to access credit on terms that approximate modern repo transactions. The significance of this innovation was well understood at the time and praised by many writers (for example, Melon 1754, Johann Philipp Graumann 1762, Lemoine de L'Espine and Le Long 1763, Adam Smith 1776 [1976], James Steuart 1767, and Cornelis Van der Oudermeulen 1791). Graumann, a former Prussian mint master, pinpointed the facility's key advantage, an ability to liquify merchants' collateral while enabling them to maintain control of it:

How advantageous this [facility] must be for the merchant community, can be seen from the fact that
with this facility, the merchant can put into motion and utilize all the monies [trade coins] that accrue
to him. ... By this means the money is effectively doubled, or twice put at the disposal of commerce,
since the merchant can make use of practically all of the capital that he has placed in the Bank. In
addition, he remains master of this money, and by repayment of the sum advanced, is authorized to
either withdraw it himself or sell it to others (Graumann 1762,137).

Grauman also noted (ibid., 136) that repo liquidity worked in both directions: coins that were eligible for repo circulated at a premium over those that were not.

\section{Parallels with the present}

We argue that the three factors that led to Phoonsen's 1677 proposal are present in U.S. dollar markets today. Safe assets, particularly U.S. Treasury securities, are available in abundant supply; demand for central bank balances (commercial banks' reserve accounts at the Federal Reserve) remains strong despite historically elevated levels of reserves; and the cost of converting one of these assets into another, as reflected in market repo rates, has of late been somewhat unpredictable.

The abundance of safe assets derives from the stance of U.S. fiscal policy. Total U.S. debt held by the public (net of intergovernmental holdings) was about $\$ 16.2$ trillion at the end of June 2019, of which only a relatively small portion ( $\$ 2.1$ trillion) was held by the Federal Reserve. ${ }^{20}$ Such debt serves as the world's leading safe asset, and current projections call for the stock of U.S. debt to increase by

\footnotetext{
${ }^{17}$ Mees $(1838,138-39)$ indicates that contemporary Dutch law viewed safe harbor as equivalent to a right to confiscation, a right that could only be granted to a public institution such as the Bank.

${ }^{18}$ Gold was more difficult to assay; furthermore, the Bank wanted Bank money to be tied more closely to silver, as it was the standard for most European countries at the time.

${ }_{19}$ Official prices of gold coins in such transactions reflected a 14-to-1 bimetallic ratio with silver, whereas a typical market ratio was 14.5 .

${ }^{20}$ For debt held by the public see Treasury Bulletin, September 2019, table FD-1. For Fed holdings of Treasury debt, see the Fed's statistical release H.4.1 Factors Affecting Reserve Balances for July 5, 2019.
} 
about $\$ 1$ trillion a year over the next ten fiscal years. ${ }^{21}$ An integral part of the appeal of such debt is its liquidity value, in particular the fact that such liquidity can be easily tapped via dense repo markets.

Expansionary monetary policy conducted in the wake of the global financial crisis has meant that reserves are abundant by historical standards (currently about $\$ 1.5$ trillion versus about $\$ 10$ billion in mid-2008). There are reasons, however, to believe that such large reserve balances are sometimes inadequate to allow for the smooth functioning of U.S. dollar money markets. One underlying factor contributing to reserve demand is the liquidity-intensive nature of Fedwire, the Fed's system for largevalue interbank payments, including transactions in Treasuries. Paralleling seventeenth-century Amsterdam, such payments are full-on transfers of central bank balances from one party to another, with no netting involved. ${ }^{22}$

Demand for reserves has also been boosted by regulations adopted in the wake of the global financial crisis, which have induced banks to maintain large reserve balances in preference to other assets, due to reserves' ability to instantaneously discharge payment obligations. ${ }^{23}$ Simultaneously, payment of interest on reserves has lowered the opportunity cost of holding them. ${ }^{24}$ Some commentators have also argued that postcrisis capital regulation has reduced the ability of large banks (known G-SIBs, or Global Systemically Important Banks) to trade reserves. ${ }^{25}$ Finally, a recent Fed survey of Senior Financial Officers (Board of Governors of the Federal Reserve System 2019) suggests that another major factor behind the increased demand for reserves is simply precaution, manifested as banks' rigorous adherence to internal liquidity management guidelines.

This combination of abundant Treasuries (and hence a desire to tap their liquidity) and enhanced demand for reserves has created conditions where supply or demand shocks can lead to volatile prices in exchanges of these two assets. The most critical market for such trades is the overnight repo market, in which Treasuries are often used as collateral. Some context is necessary here: not all participants the repo markets have access to reserve accounts at the Fed, not all repo trades are overnight, and Treasuries are not the only form of repo collateral. ${ }^{26}$ Nonetheless, because central players in Treasury repo market (banks and government-sponsored enterprises or GSEs) engage in such transactions through accounts at the Fed, rates paid in this market reflect the price of temporarily swapping Treasuries for central bank balances.

\footnotetext{
${ }^{21}$ See Congressional Budget Office, An Update to the Budget and Economic Outlook, August 2019.

22 Modern terminology designates systems such as Fedwire as "real-time gross settlement" or RTGS systems. For a recent commentary on the impact of RTGS architecture on the demand for central bank balances, see Kaminska (2019). Repo market participants have created infrastructures to lessen the liquidity demands of trading. These include 1) tri-party repo, in which transfers of both collateral and funds occur on the books of a commercial bank, BNY Mellon, and 2) clearing of some bilateral (non-tri-party) repo transactions through a central counterparty, Fixed Income Clearing Corporation, or FICC. See Pozsar (2019) for insightful descriptions of different segments of the repo market.

${ }^{23}$ Ihrig (2019) describes two regulations that have encouraged the holding of reserves: 1) the requirement that banks maintain a minimum ratio of liquid assets (the liquidity coverage ratio, or LCR) and 2) a requirement that large moneycenter banks maintain sufficient liquid assets in their plans for orderly resolution in adverse events (known as "living wills"). The LCR recognizes reserves and government securities as having equal liquidity, but in practice both banks and their regulators appear to prefer reserves.

${ }^{24}$ The Emergency Economic Stabilization Act of 2008 granted the Fed the authority to pay interest on reserves.

25 The regulation most often mentioned in this context is the G-SIB surcharge (see, for example, Covas and Nelson 2019). The G-SIB surcharge is a capital requirement applied to banks judged by regulators to be of systemic importance, as measured by a quantitative score. Some commentaries suggest that G-SIBs often refrain from trading activities that would push their score past a threshold that would increase their surcharge.

26 The total size of U.S. dollar repo markets is about $\$ 4$ trillion (counting repo and reverse repo transactions) for the bilateral segment of the repo market, which is about 70 percent in Treasuries (Kolchin, Podziemska, and Toomey 2019). Total volume is about $\$ 2.5$ trillion in the tri-party and GCF (general collateral finance) segments of repo market, with about half in Treasuries (Federal Reserve Bank of New York 2019c).
} 
Such trades are in principle risk-free and might appear interchangeable, but actual prices paid in these transactions are sometimes far from uniform. The Federal Reserve Bank of New York compiles several measures of overnight Treasury repo rates, the broadest of these being the Secured Overnight Financing Rate (or SOFR; see Federal Reserve Bank of New York 2019a). Beginning in April 2018, the New York Fed has also published a distribution of rates used to calculate SOFR as well as the SOFR itself, a volume-weighted median rate. Figure 2 shows a time series of SOFR and the interquartile range for overnight Treasury repo rates. Notable in the series are the observations for September 17, 2019, when SOFR came in at 5.25 percent, more than double the value for the previous business day. On the same day, the interquartile range for repo rates widened to 360 basis points (3.6 percent) from a more normal range of 15 basis points a day earlier.

\section{Figure 2}

Overnight Treasury Repo Rates, April 2018-November 2019

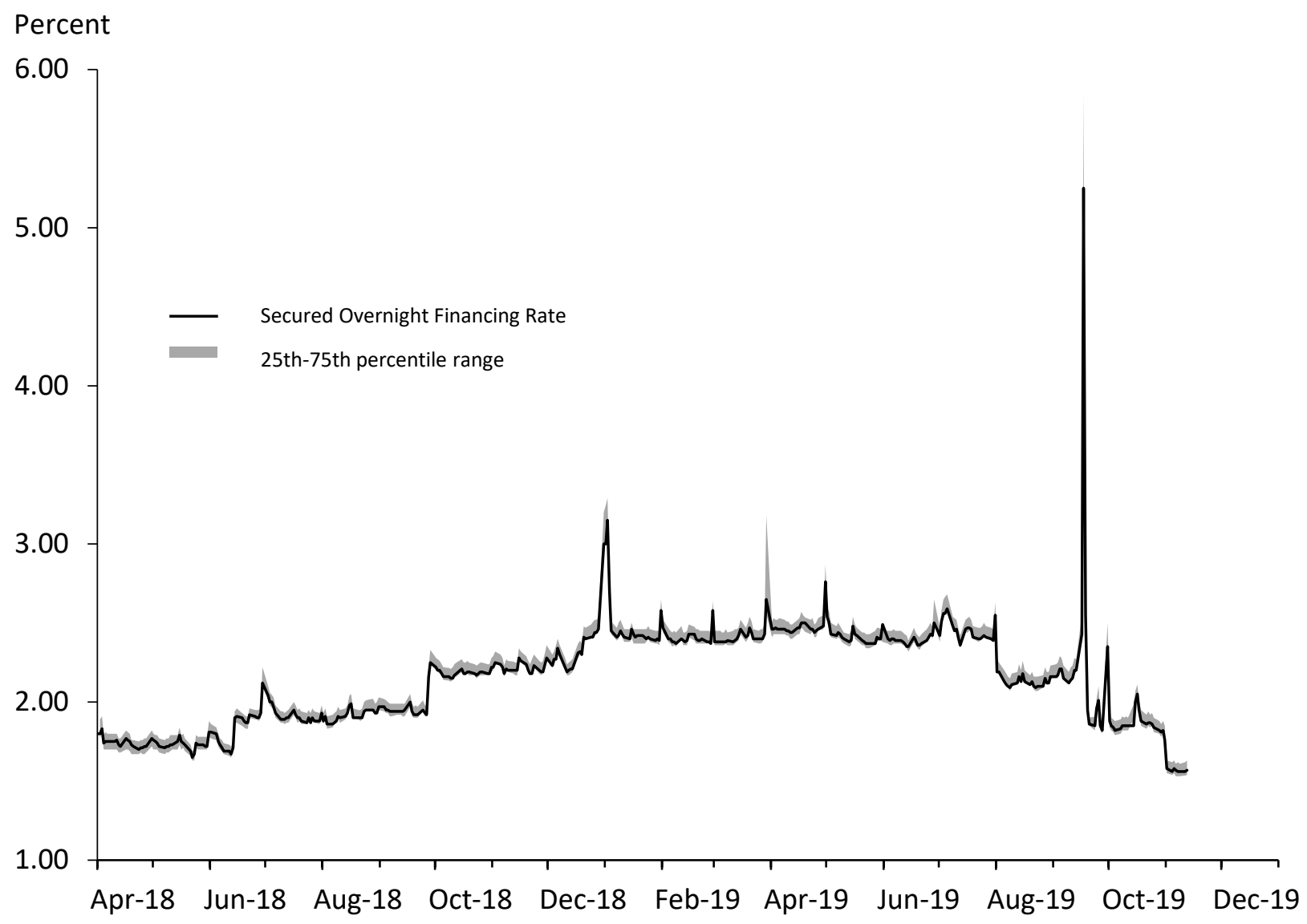

Source: Federal Reserve Bank of New York

Volatility in repo rates is a source of concern to the FOMC, because this volatility can spill over to interest rates in the fed funds market. ${ }^{27}$ The FOMC's policy decisions specify a target range for the average fed funds rate. Spillovers between the two markets can occur because the banks and GSEs that tend to be active in the fed funds market are also players in repo markets. Figure 3 shows the evolution of the effective fed funds rate (a weighted average) since the beginning of 2018

27 The fed funds market consists of overnight unsecured loans between banks and some GSEs. 
compared with the target range for this rate specified by the FOMC. The effective rate has at times been close to the top of the Committee's target range and broke above it on September 17, when repo rates spiked.

\section{Figure 3}

Effective Fed Funds Rates and FOMC Target Ranges, January 2018-November 2019

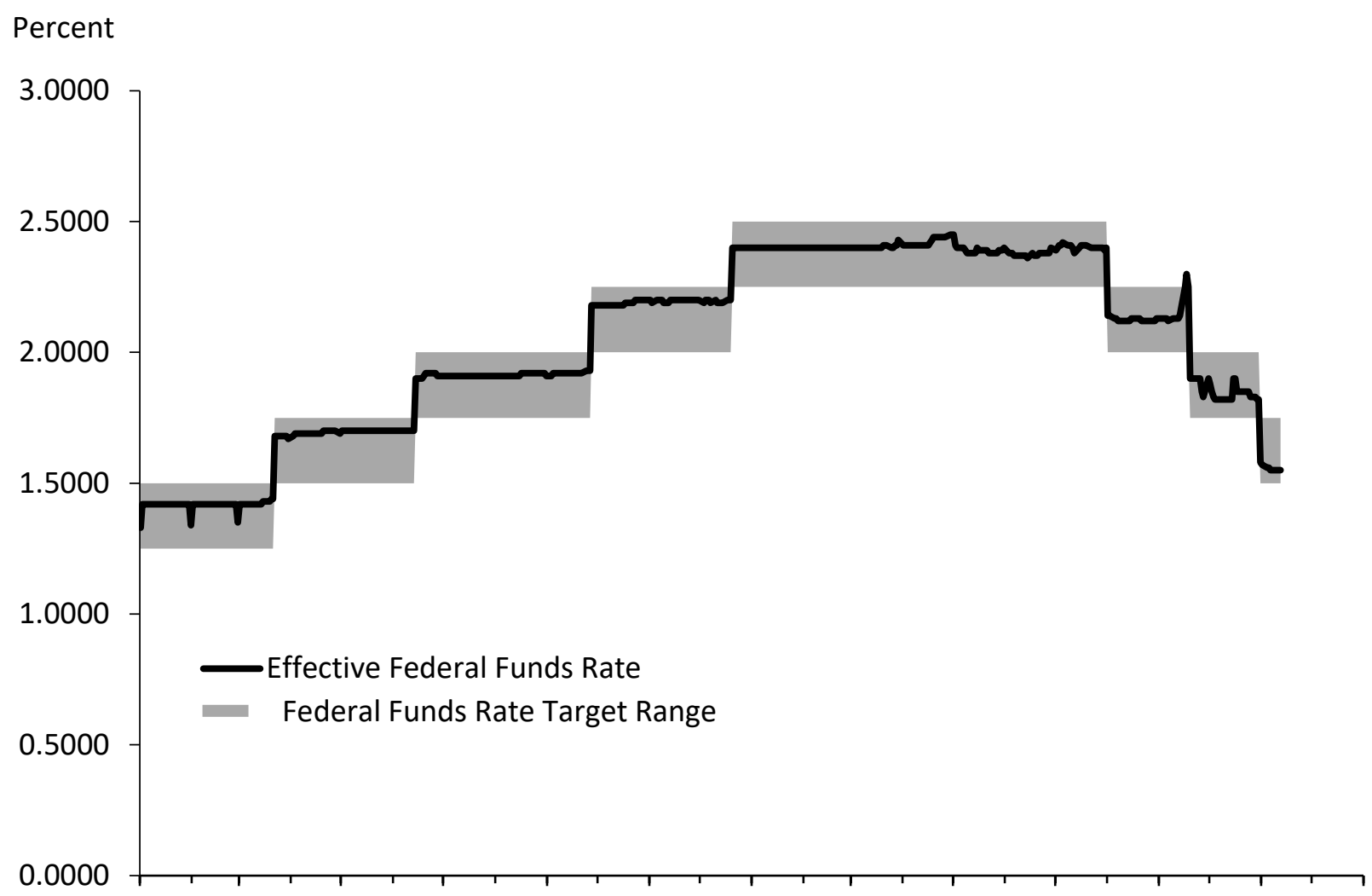

Jan-18 Mar-18 May-18 Jul-18 Sep-18 Nov-18 Jan-19 Mar-19 May-19 Jul-19 Sep-19 Nov-19

Source: Federal Reserve Board

Explanations offered for the volatility in money market rates have been variations on a theme of "too many safe assets chasing too few reserves." 28 A number of factors are thought to have contributed to downward pressure on the stock of reserves, as shown in Figure 4. Among these have been continued growth in currency and fluctuations in other Fed liabilities (these include the Treasury's account at the Fed and the FOMC's reverse repo facilities). A more prominent factor, however, has been the policy of gradual reduction in the FOMC's System Open Market Account (SOMA) portfolio holdings. This policy of "balance sheet normalization" began in October 2017 and continued until August 2019, and during this period the stock of reserves at the Fed shrank from $\$ 2.2$ trillion to $\$ 1.5$ trillion. Reserves contracted further through early September 2019 , and by mid-month, these fell to $\$ 1.4$ trillion, largely the result of increased Treasury balances at the Fed. ${ }^{29}$

28 See, for example, Nelson (2019) or Tran (2019). Smith (2019) focuses on market segmentation as a contributing factor.

${ }^{29}$ Figures for reserves are from the Fed's weekly statistical release, H.4.1: Factors Affecting Reserve Balances. 
Figure 4

Federal Reserve Liabilities, January 2008-November 2019

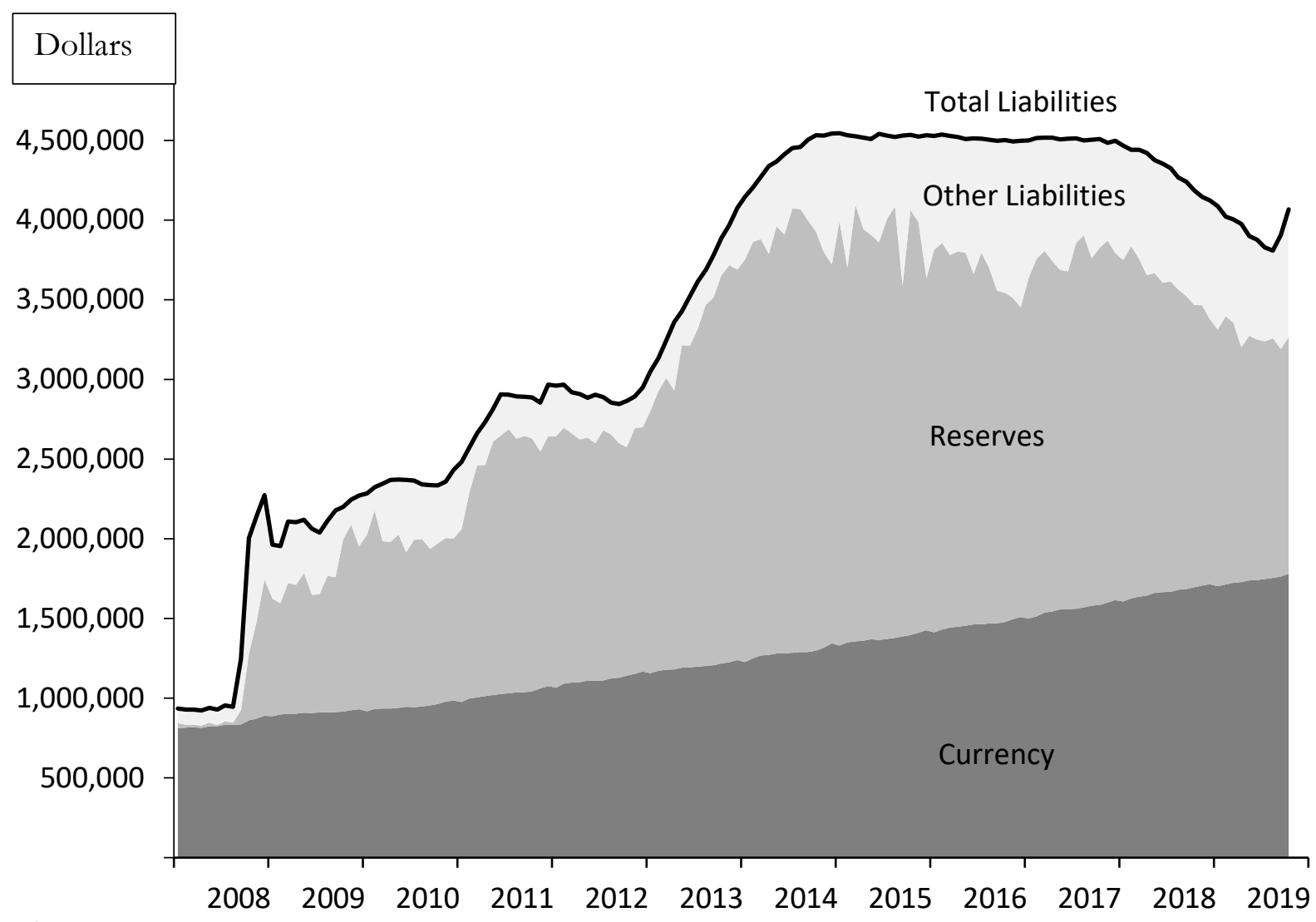

Source: Federal Reserve Board

Beginning on September 17, 2019, with the breach of the top of the fed funds target range, the New York Fed's Open Market Desk began daily repo operations to expand the supply of reserves. Over the course of the next month, the Desk also conducted term repo operations to bridge the September quarter end. On October 11, 2019, the FOMC announced a plan to continue overnight and term repos at least through January 2020 and to begin outright purchases of U.S. Treasury bills. As noted in this article's introduction, these actions are designed to reduce money market pressures by making more reserves available to banks. The effect of these actions has been to reverse the downward trend in reserves experienced during balance sheet normalization. Jerome Powell, chair of the Federal Reserve Board of Governors, has emphasized, however, that the FOMC views the recent increase in the Fed balance sheet as a technical factor rather than a shift in monetary policy (Federal Open Market Committee 2019c).

\section{The Andolfatto-Ihrig proposal}

Andolfatto and Ihrig (2019a, b) propose a different mechanism to ensure availability of reserves to the money markets. The basic idea of their proposal runs parallel to Phoonsen's: to bolster the convertibility of safe assets to central bank balances, not through discretionary open market 
operations, but by opening a standing repo facility for Treasuries. Certainty about convertibility of Treasuries, they argue, could actually lead to a reduction in the demand for reserves:

\section{The Fed could easily incentivize banks to reduce their demand for reserves by operating a standing overnight repurchase (repo) facility that would permit banks to convert Treasuries to reserves on demand at an administered rate.}

In a second parallel to Phoonsen's proposal, the Andolfatto-Ihrig proposal envisions that such credit would be made available at a low cost. A notable difference between the modern and historic proposals, however, is that a Fed facility would need to operate in the context of an active private repo market:

This administered rate could be set a bit above market rates_-perhaps several basis points above the top of the federal funds target range — so that the facility is not used every day, but only periodically when a bank needs liquidity or when market repo rates are elevated.

In a third parallel, Andolfatto and Ihrig state that their proposed facility would be immune from stigma, due to the quality of assets involved:

There are several other reasons why introducing a standing repo facility makes sense. First, as discussed here, it is a way for the Fed to lend cash to banks that are in good standing and have high-quality Treasury securities as collateral but may find themselves short of cash. Importantly, this facility would not suffer from stigma problems that make the discount window an ineffective tool in these circumstances.

As was the case with Phoonsen's plan, Andolfatto and Ihrig envision fairly broad access to the facility. They recommend giving all banks access (Andolfatto and Ihrig 2019b). ${ }^{30}$

\section{The Amsterdam experience}

Andolfatto and Ihrig (2019b) suggest that implementation of a standing repo facility would reduce banks' precautionary demand for Fed balances by creating a consistently accessible and relatively inexpensive means of exchanging U.S. Treasuries for bank reserves. Through this channel, they estimate a standing repo facility could reduce banks' reserve demand by $\$ 175$ billion to $\$ 300$ billion (as much as 20 percent from current levels).

The Bank of Amsterdam's implementation of a standing repo facility had the opposite effect. Balances at the Bank of Amsterdam expanded from 6.5 million florins immediately before implementation of the facility (yearend 1682) to 10.2 million at yearend 1687, a 57 percent increase over five years (Van Dillen 1934, 119). ${ }^{31}$ Figure 5 indicates that this balance sheet increase was driven almost entirely by the inflow of trade coins into the Bank's new standing facility (Quinn and Roberds $2014,6)$. The daily secondary market for Bank balances continued to operate and the market agio

\footnotetext{
${ }^{30}$ Other possibilities would be to limit access to large banks, to include primary dealers in Treasury securities (with whom the Fed routinely transacts in open market operations), or to include a broad cross-section of participants in the repo markets. See Pozsar (2019) for a discussion of these design options. Amsterdam's historic facility was open to any merchant with an account at the Bank, but in practice it was most heavily used by banks and other firms specialized in financial transactions.

${ }^{31}$ Figure 1 shows that the bank florin was a separate unit of account applied to Bank balances.
} 
stabilized in the range of 4 percent to 5 percent (unfortunately, few records survive of transactions in this market).

\section{Figure 5}

Bank Balances and the Introduction of a Standing Facility, 1674-94

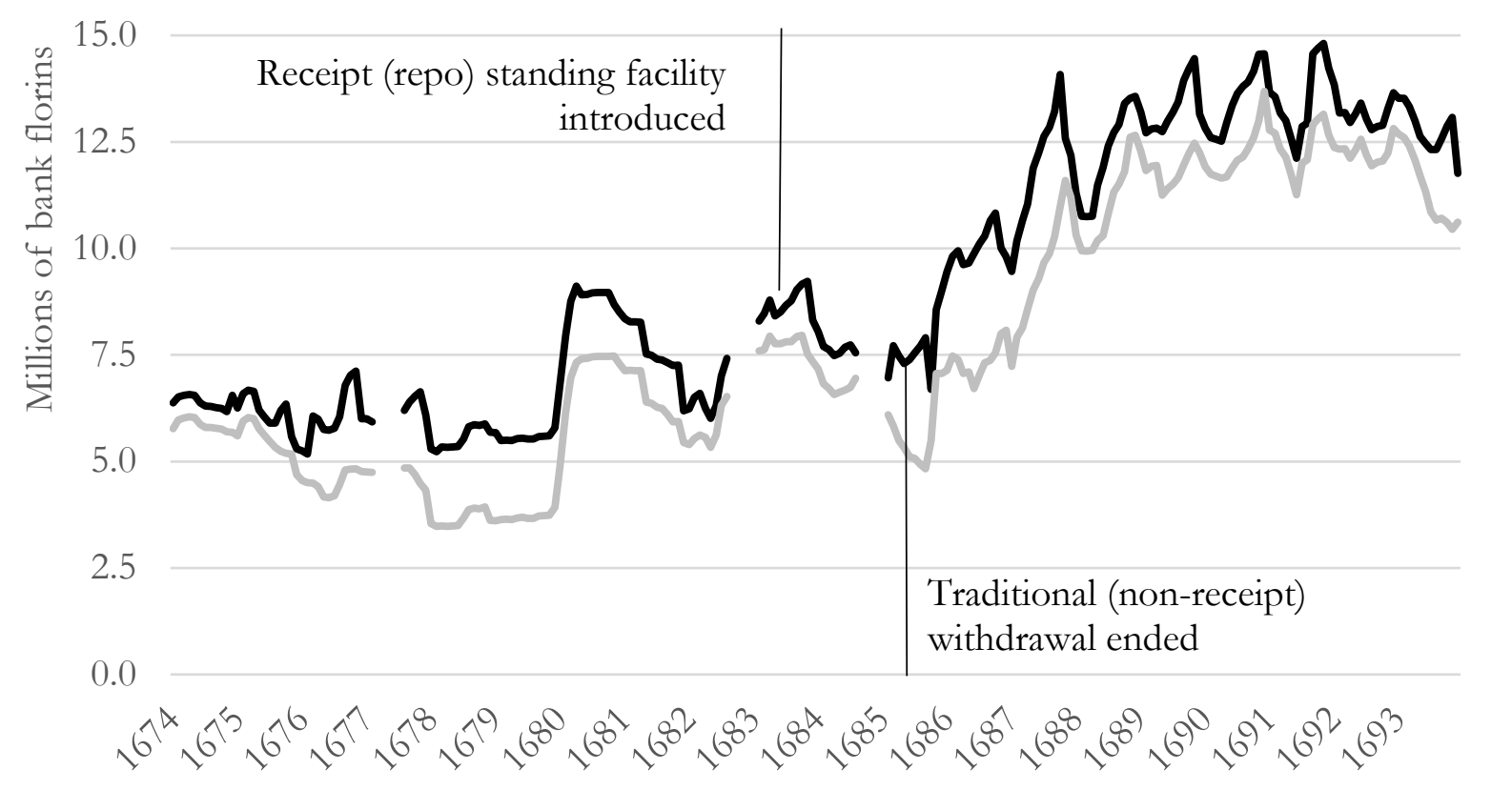

Monthly observations, series gaps from lost records

- Monetary liabilties — Backing coins

Source: Quinn and Roberds (2014)

Introduction of a standing repo facility was transformative for the Bank, expanding not only its quantitative footprint but also its qualitative nature. With so many receipts outstanding, merchants wishing to withdraw coin from the Bank now found it cheaper to buy a receipt and exercise the redemption option (that is, close out the repo) rather than execute a traditional withdrawal. Consequently, the largely unused right to withdrawal (without a receipt) was abolished sometime around 1685, and Bank balances became a de facto fiat money.

The availability of cheap secured funding also enhanced the Bank's international stature. European merchants often judged that trade coins were more liquid in repo-enabled, capital-controlfree Amsterdam than elsewhere (Van Dillen 1964a), and Amsterdam became the epicenter of Europe's credit networks. ${ }^{32}$ Merchants in foreign cities could borrow (unsecured) by drawing bills on Amsterdam merchants, who in turn could cheaply fund themselves via the Bank's repo facility. ${ }^{33} \mathrm{By}$ the eighteenth century, Bank balances functioned as a Europe-wide vehicle currency: le florin européen

\footnotetext{
32 On contemporary credit networks, see for example Van Dillen (1964a), Gillard (2004), Flandreau et al. (2009a), Carlos and Neal (2011), and Dehing (2012).

33 The mechanics of the bill transactions are somewhat involved. For examples, see Neal (1990). The underlying idea was to tap the highly liquid Amsterdam money market by swapping local money for Dutch funds.
} 
or the Euro-florin in the terminology of Gillard (2004). The bank florin, the unit of account for Bank balances, thus came to play a role not unlike that of the U.S. dollar today (Eichengreen 2018).

How big in fact was the Bank's repo pool? Table 1 breaks down stocks and flows of metal through the Bank's facility for different time periods over 1736-91, when Bank records are most complete. To give a sense of scale, the table also reports total production from New World mines for the same periods. ${ }^{34}$

\section{Table 1}

Usage of the Bank's Repo Facility, 1736-91

\begin{tabular}{|c|c|c|c|c|c|c|}
\hline \multirow{2}{*}{ Period } & \multicolumn{3}{|c|}{ Silver } & \multicolumn{3}{c|}{ Gold } \\
\cline { 2 - 7 } & $\begin{array}{c}\text { Repo'd at } \\
\text { the Bank }\end{array}$ & $\begin{array}{c}\text { Repo inflow/ } \\
\text { outflow }\end{array}$ & $\begin{array}{c}\text { New World } \\
\text { production }\end{array}$ & $\begin{array}{c}\text { Repo'd at } \\
\text { the Bank }\end{array}$ & $\begin{array}{c}\text { Repo inflow/ } \\
\text { outflow }\end{array}$ & $\begin{array}{c}\text { New World } \\
\text { production }\end{array}$ \\
\hline $1736-55$ & 66.1 & $51.9 / 55.6$ & 370 & 0.3 & $0.7 / 0.7$ & 15.8 \\
\hline $1756-65$ & 147.3 & $112.9 / 103.7$ & 424 & 1.1 & $1.7 / 1.6$ & 14.3 \\
\hline $1766-80$ & 110.7 & $53.3 / 56.8$ & 491 & 0.8 & $0.9 / 0.9$ & 15.5 \\
\hline $1781-91$ & 34.3 & $52.1 / 56.9$ & 597 & 0.4 & $0.5 / 0.5$ & 15.4 \\
\hline
\end{tabular}

Note: All figures are annual averages and expressed in metric tons.

Sources: Silver and gold production figures are from TePaske and Brown (2010, 56, 113). Repo figures are from Quinn and Roberds (2019).

During the first 20 years of the sample (1736-55), an average 66 metric tons of silver was held at the Bank under receipt, with 52 tons flowing in and 56 tons flowing out of the facility during a typical year. That pace of throughput has the Bank's facility channeling about 15 percent of New World silver production. Activity is much lighter for gold, reflecting gold coins' less favorable pricing at the facility. Levels and throughput pick up during the following decade (1756-65), a period that encompasses a global military conflict, the Seven Years War. The peak year was 1764, when 320 tons of silver were housed under receipt at the Bank, equal to about two thirds of New World silver production for that year (TePaske and Brown 2010, 113). In contrast, the final decade of the sample (1781-91) sees usage fall off as a result of the consequences of the Fourth Anglo-Dutch War (178084), described in detail below.

On the whole, these figures confirm that the Bank of Amsterdam's standing repo facility attracted significant amounts of gold and silver trade coins, the predominant safe assets of this era.

\section{From repo facility to policy framework}

To modern observers, the interest rates charged by the Bank for redeeming receipts are recognizable as monetary policy rates. Interestingly, a policy that the Bank did not consider was to systematically vary the interest rates for receipts in response to changes in market conditions. The archives of the Bank only record only two such changes (an increase for one minor type of silver coin in 1765, and in 1776 a reduction for gold coins to $1 / 4$ percent). The practice of purposely shifting policy rates, now

\footnotetext{
34 Mines in the New World contributed about 85 (70) percent of world silver (gold) production during the early modern era (1500-1800), and these mines were the source of virtually all coins that found their way to the Bank. The turnover figures in the table understate the total churn in Amsterdam's repo market, since much of the trading was done via handto-hand exchanges of receipts, outside the Bank.
} 
considered to be the essential channel of monetary policy, would have to await its development by the Bank of England in the nineteenth century (Ugolini 2017). ${ }^{35}$

Instead of shifting policy rates, the Bank engaged in active (outright) policy operations. These operations were not applied to consciously manage macroeconomic outcomes, as occurs with modern central banks, but instead were apparently applied (apparently, since the Bank did not record rationales for most of its actions) with the goal of managing liquidity available to Amsterdam's financial markets. $^{36}$

A closer analysis of the Bank's balance sheet offers some insights into the Bank's policy framework. Trade coins held under receipt were not the only asset held by the Bank. Other types of assets included loans and stocks of coin owned outright (unencumbered by options to withdraw). Unencumbered coins were either those whose receipts had expired or those that the Bank acquired through outright open market purchases. The Bank granted loans to only a few privileged counterparties, including the Dutch East India Company and the Bank's owner, the City of Amsterdam.

We can visualize the Bank's policy framework by dividing up Bank balances, based on the composition of the Bank's backing assets. More specifically, we can think of the total stock of Bank balances $M$ as being backed by three assets:

- Coins obtained through repos $E$ (where E stands for "encumbered by receipts")

- Unencumbered coins $U$

- Loans $L$

As an identity, ${ }^{37} M=E+U+L$

Figure 6 shows this breakdown.

\footnotetext{
35 Ugolini (2013) shows that the late nineteenth-century Bank of England made extensive use of policy tools other than interest rate changes, including outright operations in metallic assets and reverse repos in government securities.

${ }^{36}$ In the one surviving directive from the City, the Bank is instructed to engage in open market operations to keep the agio between 4 percent and 5 percent but to forgo such operations when "circumstances are not advantageous" (Van Dillen 1925, 433-34). Quinn and Roberds (2019) present formal evidence that, in practice, quantitative management of the Bank's money stock often took precedence over agio stabilization.

37 Technically, one of these components must be adjusted for the equity position of the Bank, which was usually quite small. Applying this adjustment, $L$ is equal to loans less equity.
} 
Figure 6

Monetary Liabilities by Backing Asset, 1736-91

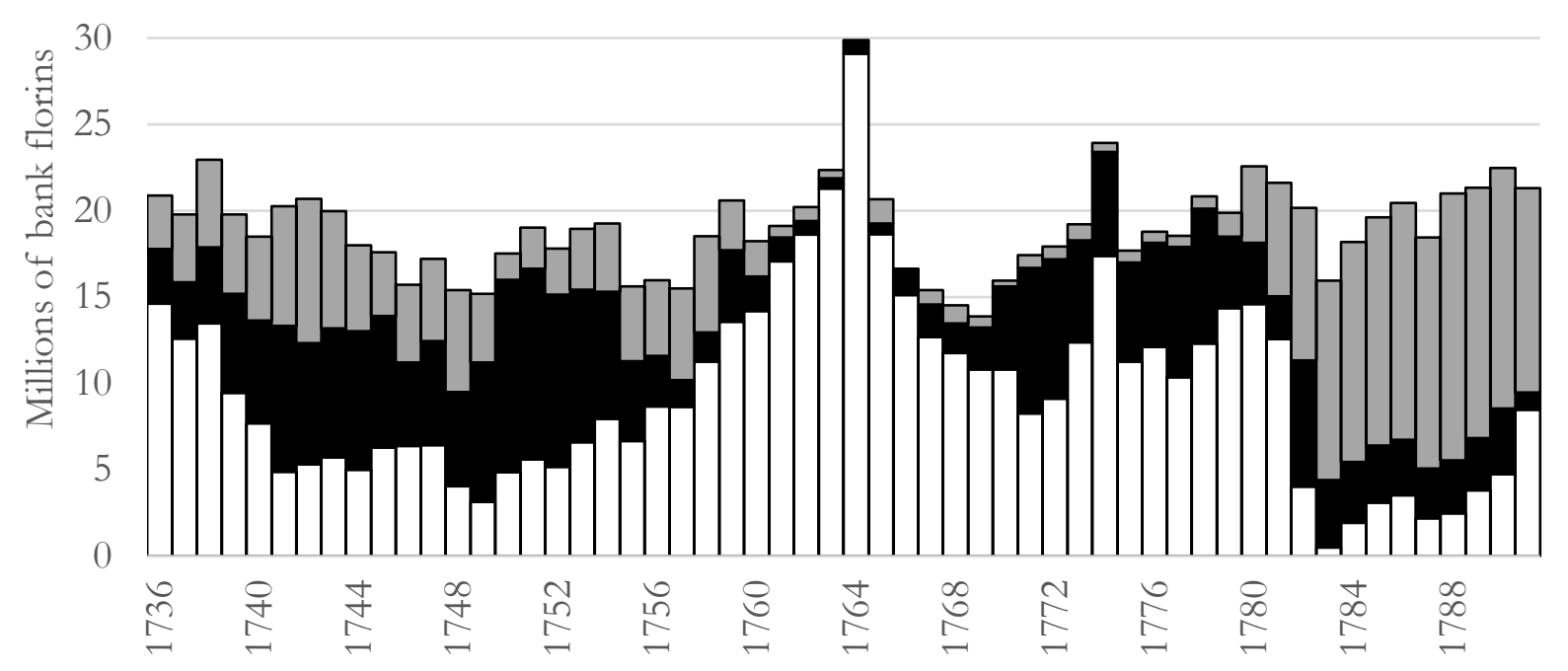

Observations annual on July 1

$\square$ Coins under receipt (repo) $\quad$ Coins owned outright $\square$ Unsecured loans less equity

Source: Quinn and Roberds (2019)

The figure suggests that for most of this sample, the Bank reacted to fluctuations in balances arising from the repo facility. Changes in balances backed by repo $E$ tended to be offset by corresponding changes in other components: $E$ varied from a high of 29 million florins (1764) to a low of 516,000 florins (1783). By contrast, the total stock of Bank balances $M$ tended to fluctuate around an apparent target level of 18 million to 20 million bank florins, except for a period around the end of the Seven Years War (1763 and 1764 in figure 6).

This pattern is more evident in figure 7. 
Figure 7

Monetary Liabilities in Two Parts, 1736-91

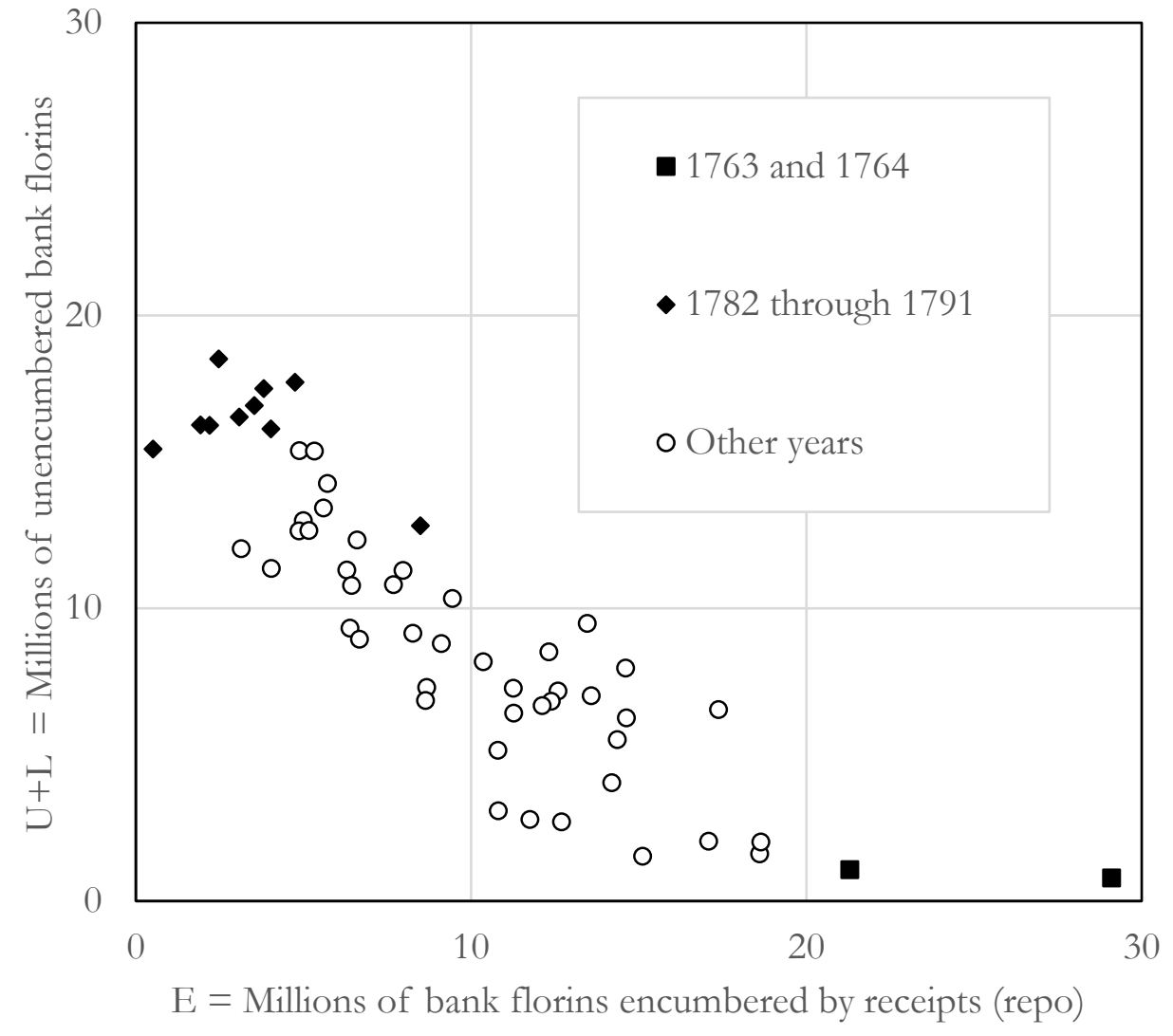

Observations annual on July 1

Source: Quinn and Roberds (2019)

This figure plots balances backed by repos $E$ against the sum of the other two components $U+L$. The figure shows a strong negative relationship, and a regression line fit through these data has a slope of -.98: perfect offset would imply a slope of -1.0. The chart suggests that a major focus of the Bank's policy was the offset ("sterilization" in modern central banking jargon) of changes in Bank balances arising from its standing repo facility. Such sterilization controlled the total amount of Bank balances available to the Amsterdam financial markets and, most critically, the market for bills of exchange.

How was such sterilization accomplished? Throughout this sample, the Bank engaged in outright transactions in coins that were either ineligible or unattractive for repo. The most common asset in such transactions were small-denomination (one-guilder) Dutch coins, which were typically only used in local transactions and were ineligible for repo. On numerous occasions the Bank also liquidated gold trade coins that had fallen to the Bank from expired receipts.

The Bank's policy framework was constrained by its relationship with its owner, the City of Amsterdam. The City allowed the Dutch East India Company to borrow large sums from the Bank 
in the form of advances, which were nominally secured against cargoes returning from Asia. The Bank had little control over the timing and magnitude of such loans.

\section{What could go wrong, eventually did}

As the foundation of Amsterdam's financial markets, the Bank's standing repo facility worked well for long periods. Predictable access to liquidity reinforced Amsterdam's status as a financial center. Merchants throughout Europe could tap this liquidity by drawing bills payable through the Bank (as a way of borrowing funds), and they often expected their counterparties to do the same. There were, however, two periods when the Bank's repo-oriented policy framework proved fatefully inadequate: the end of the Seven Years War (late 1762 through early 1765) and the period of the Fourth AngloDutch War (1780-84) and its aftermath. These stress periods are clustered near the axes in figure 7. Each of these incidents has useful modern parallels.

\section{The first incident: 1762-65}

Throughout the Seven Years War (1756-63), demand at the repo facility was extraordinary (stocks and flows of collateral doubled from previous decades, as table 1 shows). Following its traditional policy framework, the Bank attempted to sterilize the ensuing buildup in Bank balances by selling stocks of gold coin whose receipts had expired. The Bank sold off all its unencumbered gold coins by July 1762, but trade coins continued to pour into the Bank's repo facility. Bank balances increased and these supported elevated levels of trading in bills of exchange. ${ }^{38}$

In early August 1763, a major Amsterdam merchant banker failed along with his Berlin counterparty, leading to multiple rounds of failures in many locations throughout northern Europe (De Jong Keesing 1939, Rachel and Wallich 1967, Schnabel and Shin 2004). ${ }^{39}$ In Amsterdam, this shock caused a violent contraction in the bill market, which in turn led to a scramble for liquidity along two dimensions. First, merchant banks and other financially active merchants needed Bank balances to cover bills of exchange they had already agreed to pay. Since unsecured funding had dried up for many participants, the surest way to obtain Bank balances was to sell trade coins to the Bank via the repo facility. Second, these merchants also needed coin to settle obligations outside the Bank.

The parties most exposed to this double-edged scramble were the cashiers, the brokers in the daily market for Bank money. The liquidity of the cashiers became suspect and runs occurred as customers withdrew balances held with cashiers. ${ }^{40} \mathrm{~A}$ week into the panic, the market for Bank funds became completely dysfunctional, and the bank florin "broke the buck" - the market agio went negative-as cashiers attempted to shed Bank balances in favor of coin needed to meet customers' demands (De Jong Keesing 1939, 165). Loss of value of the bank florin, the numeraire in Amsterdam's financial markets, risked the credibility of the Bank itself.

The Bank was able to avert disaster by means of a well-conceived policy response. This was to broaden the class of assets eligible for repo to include "junk collateral" in the form of silver bullion.

\footnotetext{
38 The annual number of payments through the Bank, used to trade and settle bills, increases from about 110,000 in 1750 to nearly 160,000 by the end of the Seven Years War (Dehing 2012, 82).

${ }^{39}$ The failed Amsterdam and Berlin merchants (Leendert Pieter de Neufville and Johann Ernst Gotzkowsky) had partnered in a massive, highly speculative deal to buy the Russian army's unused horse fodder left in Prussia at the end of the Seven Years War. When financing for the deal fell through, Neufville and Gotzkowsky defaulted on hundreds of creditors across Europe, notably including the Russian Empress Catherine the Great. Settlement of Catherine's claim involved transfer of an extensive art collection that is now owned by the Hermitage museum (Ris 2016).

40 Although the cashiers' original function was brokering money transactions, in this era of light regulation they also engaged in investment activities, or in Phoonsen's words, "played with the money of their masters."
} 
Silver bullion was abundant in Amsterdam at war's end, thanks to Prussia's May 1763 decision to demonetize its debased war coinage. Much of the Prussian coin was melted down and shipped to Amsterdam for refining, so much that immediate processing was far beyond the capacity of Dutch mints and private smelters. ${ }^{41}$ Until it could be refined, however, the heavily alloyed Prussian silver could not function as money. Since this junk collateral could ultimately be converted to trade coin at a reasonably predictable cost, however, it carried little long-term risk to the Bank.

Under the Bank's emergency policy, merchants could use silver bullion to access central bank funds without tying up safe assets (trade coins), which they could now employ elsewhere. Repos in raw silver carried a penalty interest rate $(1 / 2$ percent for six months versus $1 / 4$ percent for silver trade coin) and a haircut of 7 percent relative to market price. This new liquidity channel, though lightly used under this pricing structure, shored up the liquidity of key market participants and broke the psychology of the panic. Overall demand at the repo facility surged and then receded, and roughly normal conditions were restored by late 1765 (Quinn and Roberds 2015).

The incident points out one of the inherent dangers of a central bank standing repo facility: in troubled times, market participants prefer to deal with it rather than with less protected institutions. Andolfatto and Ihrig emphasize that the Fed's services should be priced so that only the occasional customer will find it preferable to use those services. But in times of crisis, most customers will suddenly prefer the Fed over private dealers in repo at the going price differential.

On the one hand, this is good news: customers have a safety net in the case of the failure of the private repo market. On the other hand, just like the Bank of Amsterdam, the Fed has an interest in maintaining the stability of its erstwhile competitors. Note that the problem could arise from either a sudden increase in demand for the safe asset or a sudden increase in demand for central bank reserves. Or, as happened in 1763, there could be a simultaneous scramble for both assets. Such situations may require a carefully designed response in order to satisfy market demands for liquidity without signaling a permanent shift in the stance of policy. ${ }^{42}$

\section{The second incident: $1780-84$}

A more serious crisis began in 1780, with the outbreak of the Fourth Anglo-Dutch War. During the war, the English navy seized many ships of the Dutch East India Company returning from Asia, throwing the Company into de facto bankruptcy. The Bank was pressured to roll over unpaid credits it had extended to the Company, and in 1783 these were forcibly exchanged for shaky long-term Company bonds. The Bank's repo facility became abandoned over 1781-83, as receipts were redeemed and little new collateral came in. The receipts issued by the Bank had been designed as call options on trade coins, but the market now saw these as convenient put options on Bank balances, options that were exercised en masse. ${ }^{43} \mathrm{~A}$ standing repo facility designed for good times now became a potent enabler of a currency run.

The Bank's policy framework once again proved inadequate for these developments. As repos were unwound from 1781 to 1783, the Bank followed its playbook by sterilizing this drain through outright open market purchases. The Bank's ongoing support of the Company, however, soon led

\footnotetext{
${ }^{41}$ Dutch provincial mints ran at peak capacity over 1763 and 1764 in an attempt to process available bullion into usable coin (Polak 1998). Private-sector refining of melted-down Prussian war coin continued until 1769 (Zappey 1982, Müntz, 1769-1770).

42 For the Bank, such a shift would have been acceptance of a permanent reduction in the market agio. For a modern central bank, this could be manifested as a change in its weighting of growth versus inflation targets, or a shift in these targets.

${ }^{43}$ Note that the unwinding of merchants' repos with the Bank, in which Bank balances were returned in favor of collateral, was in the opposite direction of the famous repo run experienced by Lehman Brothers in 2008, in which collateral was returned for cash (Copeland, Martin, and Walker 2011).
} 
markets to question the value of Bank balances. The market agio drifted downward from its normal 4-5 percent range, hitting 3 percent in 1785 and going negative by late 1790, as the Bank slid into a state of "policy insolvency." " 44 Some defensive tightening operations were attempted in the form of outright open market sales, but the Bank lacked adequate unencumbered coin to make these operations effective. A partial recapitalization in 1791 could not restore the Bank its earlier prominence. Europe's hot money had long since migrated to places such as Hamburg and London, never to return (Van Dillen 1964c).

\section{Lessons learned}

What lessons does this historical experience offer for the design and implementation of a modern central bank standing repo facility? Again, there is good news and bad news.

\section{Lesson 1: It can work}

The good news is that since such facilities have been around since 1683, they should not be seen as experimental. If the facility is priced attractively enough to overcome stigma, one should expect that it will be quite popular with those parties who enjoy access. By making repo finance more reliable, the facility should expand the demand for repo, though in the modern world this expansion would likely be shared between private markets and the facility itself. For a global currency such as the U.S. dollar, much of this increase in demand would stem from an expansion of dollar credit abroad.

\section{Lesson 2: Active management may be required}

The bad news is that popularity does not unequivocally translate to success. A standing repo facility can fundamentally change the environment in which the central bank operates. In particular, the Bank of Amsterdam belatedly discovered that the short-term options embedded in its facility could be problematic if too many of these were exercised at once. In good times, the customers of that facility were willing to roll over the options, creating the sense that the Bank was in a stable condition. The sense of stability was reinforced by the Bank's policy of sterilizing monetary fluctuations arising from usage of the facility. In bad times, however, the Bank was forced to confront the possibility of large, difficult-to-manage unwinds.

\section{Lesson 3: Management during tail events can be challenging}

In response to the 1763 crisis, the Bank risked its credibility by lowering collateral standards in order to maintain the liquidity of the financial system. This was a necessary, indeed praiseworthy, response in light of one of its objectives. However, when the crisis hit, even a crisis where the precipitating event was not associated with the Bank, the Bank's own credibility came into question. The Bank's policy gamble worked in this instance, but it was a gamble.

The 1780-84 crisis was driven by the Bank's own credit losses, and it is unlikely that any intervention could have restored the reputation of the Bank, barring a full recapitalization. The Bank was forced to watch as abandonment of its repo facility helped propel the value of Bank balances downward.

\footnotetext{
44 Traditional definitions of insolvency cannot be applied to issuers of fiat money. However, "policy insolvency," as defined by Stella and Lönnberg (2008), occurs when a central bank's balance sheet is incompatible with its policy goals. Quinn and Roberds (2016) show that from 1783, the Bank's balance sheet could not support the traditional range for the market agio of 4 percent to 5 percent. For additional discussion of how policy insolvency can arise in modern contexts, see for example Sims (2004), Benigno and Nisticò (2015), or Del Negro and Sims (2015).
} 


\section{Summing up}

Nowadays, the market for repo is already enormous, even by the standards of the Federal Reserve. The goal of the standing facility proposal is not to replace the major players of this market but to act as a backstop, with rates sufficiently uncompetitive not to be the first choice of market participants, but not so uncompetitive as to entail stigma. The facility's interest rate would, however, become a de facto policy rate governing conditions in this market, whether or not it is advertised as such. As compared to the historic case, the ability to shift policy rates can provide an extra dimension for control.

Nonetheless, management of a standing facility can be challenging, and tail events will occur. When they do, market demand for the facility may shift in amounts likely to be unanticipated based on precrisis activity. Failure to adequately prepare for such events can risk the credibility on which monetary policy depends. In short, a careful regard for the experiences of earlier, longstanding institutions in response to crisis events will be valuable for weighing the advantages and disadvantages of new proposals for financial infrastructure. 


\section{References}

\section{Primary sources}

Amsterdam City Archive (Stadsarchief Amsterdam)

The data for Table 1 and Figures 5-7 were hand-collected from the archive of the Bank of Amsterdam, held at the Amsterdam City Archive:

< archief.amsterdam/inventarissen/overzicht/5077.nl.html > (accessed January 9, 2020)

The Bank's balance sheet was reconstructed using entries from the ledgers (grootboeken) of the Bank's master account (Specie Kamer), which are available from 1666. Eighteenth-century ledger entries were correlated against the Bank's asset-side records (cash books or kasboeken) for years when the latter are available. Approximately 100,000 ledger entries were employed in constructing the table and graphs.

International Institute of Social History (Internationaal Instituut voor Sociale Geschiedenis), Amsterdam

Müntz, Johann Heinrich. 1769-70. “Ausführliche Beschreibung von dem Silber- und KupferSchmelz-Werk ... aufgericht zu Muiden bey Amsterdam, Eigenthümer davon Der Herr B. V. Ephraim, mit accuraten und vollständigen Rissen versehn.” Manuscript.

(Copy of an original in Baker Library, Harvard University)

\section{Literature cited}

Andolfatto, David, and Jane Ihrig. 2019a. Why the Fed should create a standing repo facility. Federal Reserve Bank of St. Louis On the Economy Blog, March 6. <www.stlouisfed.org/on-theeconomy $/ 2019 / \mathrm{march} /$ why-fed-create-standing-repo-facility $>$ (accessed January 9, 2020)

- 2019b. The Fed and a standing repo facility: A follow-up. Federal Reserve Bank of St. Louis On the Economy blog, April 19. <www.stlouisfed.org/on-the-economy/2019/april/fed-standing-repo-facilityfollow-up $>$ (accessed January 9, 2020)

Attman, Artur. 1986. American Bullion in the European World Trade: 1600-1800. Göteborg: Kungliga Vetenskaps- och Vitterhets-Samhället.

Barrett, Ward. 1990. World bullion flows, 1450-1800. In The Rise of Merchant Empires: Long Distance Trade in the Early Modern World, 1350-1750, edited by James D. Tracy, 224-54. Cambridge: Cambridge University Press.

Benigno, Pierpaolo, and Salvatore Nisticò. 2015. Non-neutrality of open market operations. LUISS Guido Carli/School of European Political Economy, Working Paper no. 5.

Board of Governors of the Federal Reserve System. 2019. August 2019 senior financial officer survey. $<\underline{w w w . f e d e r a l r e s e r v e . g o v / d a t a / s f o s / f i l e s / s e n i o r-f i n a n c i a l-o f f i c e r-s u r v e y-201908 . p d f ~}>$ (accessed January $9,2020)$ 
Carlos, Ann M., and Larry Neal. 2011. Amsterdam and London as financial centers in the eighteenth century. Financial History Review 18, no. 1: 21-46.

Carlson, Mark, and Jonathan Rose. 2017. Stigma and the discount window. Board of Governors of the Federal Reserve System FEDS Notes, December 19. <www.federalreserve.gov/econres/notes/fedsnotes/stigma-and-the-discount-window-20171219.htm> (accessed January 9, 2020)

Copeland, Adam, Antoine Martin, and Michael Walker. 2011. Repo runs: Evidence from the tri-party repo market. Federal Reserve Bank of New York Staff Report no. 506.

Covas, Francisco, and Bill Nelson. 2019. Bank regulations and turmoil in repo markets. Banking Policy Institute, September 26. < bpi.com/bank-regulations-and-turmoil-in-repo-markets/> (accessed January 9, 2020)

Dehing, Pit. 2012. Geld in Amsterdam: Wisselbank en wisselkoersen, 1650-1725. Hilversum: Uitgeverij Verloren.

Dehing, Pit, and Marjolein 't Hart. 1997. Linking the fortunes: currency and banking, 1550-1800. In $A$ financial history of the Netherlands, edited by Marjolein 't Hart, Joost Jonker, and Jan Luiten van Zanden, pp. 37-63. Cambridge: Cambridge University Press.

De Jong-Keesing, Elisabeth Emmy. 1939. De Economische Crisis van 1763 te Amsterdam. N.V. Intern. Uitgevers en h. Mij: Amsterdam.

Del Negro, Marco, and Christopher Sims. 2015. When does a central bank's balance sheet require fiscal support? Journal of Monetary Economics 73 (July):1-19.

Eichengreen, Barry. 2018. Banks, financial markets, and the development of international currencies. In Financial innovation and resilience: A comparative perspective on the public banks of Naples (1462-1808), edited by Lilia Costabile and Larry Neal, pp. 313-26. Cham, Switzerland: Palgrave McMillan.

Federal Open Market Committee. 2019a. Statement regarding monetary policy implementation. October 11. $<$ www.federalreserve.gov/newsevents/pressreleases/monetary20191011a.htm $>$ (accessed January 9, 2020)

- 2019b. Minutes of the Federal Open Market Committee. October 29-30.

$<$ www.federalreserve.gov/monetarypolicy/fomcminutes20191030.htm> (accessed January 9, 2020)

- 2019c. Transcript of Chair Powell's press conference. October 30.

$<$ www.federalreserve.gov/mediacenter/files/FOMCpresconf20191030.pdf> (accessed January 9, 2020)

Federal Reserve Bank of New York. 2019a. Additional information about the Treasury repo reference rates. $<$ www.newyorkfed.org/markets/treasury-repo-reference-rates-information> (accessed January 9, 2020)

_. 2019b. Statement regarding Treasury bill purchases and repurchase operations. $<$ www.newyorkfed.org/markets/opolicy/operating_policy_191011> (accessed January 9, 2020)

- 2019c. Tri-party/GCF repo. <www.newyorkfed.org/data-and-statistics/data-visualization/tri-partyrepo/index.html\#interactive/volume/collateral value $>$ (accessed January 9, 2020)

- 2019d. Statement regarding repurchase operations. <www.newyorkfed.org/markets/opolicy/operating policy 191212> (accessed January 9, 2020)

Flandreau, Marc, Christophe Galimard, Clemens Jobst, and Pilar Nogués-Marco. 2009a. Monetary geography before the Industrial Revolution. Cambridge Journal of Regions, Economy and Society 2 (July): 149-71.

Flandreau, Marc, Christophe Galimard, Clemens Jobst, and Pilar Nogués-Marco. 2009b. The bell jar: Commercial interest rates between two revolutions, 1688-1789. In The origin and development of financial markets and institutions, edited by Jeremy Atack and Larry Neal, pp. 161-208. New York: Cambridge University Press. 
Garbade, Kenneth D. 2006. The evolution of repo contracting conventions in the 1980s. Federal Reserve Bank of New York Economic Policy Review (May): 27-42.

. 2016. Repurchase agreements as an instrument of monetary policy at the time of the accord. Federal Reserve Bank of New York Staff Report no. 780 (June).

Gelderblom, Oscar, Joost Jonker, and Clemens Kool. 2016. Direct finance in the Dutch Golden Age. Economic History Review 69, no. 4: 1178-98.

Gillard, Lucien. 2004. La Banque d'Amsterdam et le florin européen au temps de la République Néerlandaise (1610_ 1820). Paris: École des hautes-études en sciences sociales.

Gorton, Gary B. 2017. The history and economics of safe assets. Annual Review of Economics 9 (August): 54786.

Gorton, Gary, and Andrew Metrick. 2010. Regulating the shadow banking system. Brooking Papers on Economic Activity (Fall): 261-312.

Graumann, Johann Philipp. 1762. Gesammelte Briefe von dem Gelde; von dem Wechsel und dessen Cours; von der Proportion zwischen Gold und Silber; von dem Pari des Geldes und den Münzgesetzen verschiedener Völker; besonders aber von dem Englischen Münzwesen. Berlin: Christian Friedrich Voss.

Ihrig, Jane. 2019. Banks' demand for reserves in the face of liquidity regulations. Federal Reserve Bank of St. Louis On the Economy blog, March 6. <www.stlouisfed.org/on-the-economy/2019/march/banksdemand-reserves-face-liquidity-regulations $>$ (accessed January 9, 2020)

Kaminska, Izabella. 2019. How RTGS inadvertently killed system liquidity. Financial Times, October 4.

Kolchin, Katie, Justyna Podziemska, and Robert Toomey. 2019. US repo market fact sheet, 2019. Securities Industry and Financial Markets Association. $<\underline{w w w . s i f m a . o r g / r e s o u r c e s / r e s e a r c h / u s-r e p o-m a r k e t-f a c t-~}$

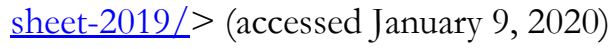

Lee, Helene, and Asani Sarkar. 2018. Is stigma attached to the European Central Bank's marginal lending facility? Federal Reserve Bank of New York Liberty Street Economics, April 16.

$<$ libertystreeteconomics.newyorkfed.org/2018/04/is-stigma-attached-to-the-european-central-banksmarginal-lending-facility.html> (accessed January 9, 2020)

Le Moine de L'Espine, Jacques, and Isaac Le Long. 1763. De Koophandel van Amsterdam. Rotterdam: Ph. Losel, J.D. Beman, H. Kentlink, J. Bosch, N. Smithof, d'wed. J. Losel en J. Burgvliet.

Mees, Willem C. 1838. Proeve eener Geschiedenis van het Bankwezen in Nederland geduerende den Tijd der Republiek. Rotterdam: W. Messcuert.

Melon, Jean-François. 1754. Essai Politique sur le Commerce. Amsterdam: François Changuion.

Neal, Larry. 1990. The rise of financial capitalism: International capital markets in the Age of Reason. Cambridge: Cambridge University Press.

Nelson, Bill. 2019. What just happened in money markets, and why it matters. Banking Policy Institute, September 18. < bpi.com/what-just-happened-in-money-markets-and-why-it-matters/> (accessed January 9, 2020)

Polak, Menno. 1998. Historiografie en Economie van de "Muntchaos." Deel II: Bijlagen. Amsterdam: Nederlandsch Economisch-Historisch Archief.

Pozsar, Zoltan. 2019. Design notes for an o/n repo facility. Credit Suisse Global Money Notes no. 25, September 9.

Quinn, Stephen and William Roberds. 2014. How Amsterdam got fiat money. Journal of Monetary Economics 66, no. 1 (September): 1-12. 
2015. Responding to a shadow banking crisis: The lessons of 1763. Journal of Money, Credit, and Banking 47, no. 6:1149-76.

- 2016. Death of a reserve currency. International Journal of Central Banking (December): 63-103.

. 2019. A policy framework for the Bank of Amsterdam, 1736-1791. Journal of Economic History 79, no. 3 (September): 736-72.

Rachel, Hugo, and Paul Wallich. 1967. Berliner Grosskaufleute und Kapitalisten. Zweiter Band: Die Zeit des Merkantilismus, 1648-1806. Expanded edition, edited by Johannes Schultze, Henry C. Wallich, and Gerd Heinrich. Berlin: Walter Gruyter.

Ris, Elena. 2016. Eremitage aus Berlin. Die Gemäldesammlung von Johann Ernst Gotzkowsky als Grundstock der Bildergalerie der russischen Zarin Katharina II. in St. Petersburg, vol. 1. Unpublished PhD dissertation, Free University of Berlin.

Schnabel, Isabel, and Hyun S. Shin. 2004. Liquidity and contagion: The crisis of 1763. Journal of the European Economic Association 2, no. 6 (December): 929-68.

Sims, Christopher A. 2004. Fiscal aspects of central bank independence. In European monetary integration, edited by Hans-Werner Sinn, Mika Widgrén, and Marko Köthenberger, 103-16. Cambridge, MA: MIT Press.

Smith, Adam. 1976 [1776]. An inquiry into the nature and causes of the wealth of nations. Oxford: Clarendon Press.

Smith, Robert Mackenzie. 2019. All clear? Structural shifts add to repo market madness. Risk, November 12.

Stella, Peter, and Åke Lönnberg. 2008. Issues in central bank finance and independence. International Monetary Fund Working Paper 08/37.

Steuart, James. 1767. An inquiry into the principles of political economy, volume II. London: Millar and Cadell.

TePaske, John J., and Kendall W. Brown. 2010. A new world of gold and silver. Leiden and Boston: Brill.

Tran, Huang. 2019. Repo turmoil is a symptom of a much bigger problem. Financial Times, September 26.

Ugolini, Stefano. 2013. The Bank of England as the world gold market maker during the classical gold standard era 1889-1910. In The global gold market and the international monetary system from the late 19th century to the present, edited by Sandra Bott, pp. 64-87. London: Palgrave McMillan.

Ugolini, Stefano. 2017. The evolution of central banking: Theory and history. London: Palgrave McMillan.

Van der Oudermeulen, Cornelis. 1791. Recherches sur le commerce ou idées relatives aux intérêts des différens peuples de l'Europe, Tome 2, Premiere Partie. Amsterdam: D.J. Changuion.

Van Dillen, Johannes Gerard. 1921. Een Boek van Phoonsen over de Amsterdamsche Wisselbank. Economisch-historisch jaarboek 7:1-146.

- 1925. Bronnen Tot de Geschiedenis der Wisselbanken; (Amsterdam, Middelburg, Delft, Rotterdam). The Hague: Martinus Nijhoff.

- 1934. The Bank of Amsterdam. In History of the principal public banks, edited by Johannes Gerard van Dillen, 79-124. The Hague: Martinus Nijhoff.

—.1964a. Amsterdam als Wereldmarkt der Edele Metalen in de 17de en 18de Eeuw. In Zeventien Studiën van Nederlanders, pp. 235-71. The Hague: Martinus Nijhoff.

- 1964b. Bloeitijd der Amsterdamse Wisselbank 1687-1781. In Mensen en Acbtergronden, Studies vitgegeven ter gelegenheid van de tachtigste jaardag van de schrijuer, edited by Johannes Gerard van Dillen, pp. 385-415. Groningen: J.B. Wolters. 
1964c. Ondergang van de Amsterdamse Wisselbank 1782-1820. In Mensen en Achtergronden, Studies uitgegeven ter gelegenheid van de tachtigste jaardag van de schrijver, edited by Johannes Gerard van Dillen, pages 417-47. Groningen: J.B. Wolters.

. 1964d. Oprichting en Functie der Amsterdamse Wisselbank in de Zeventiende Eeuw, 1609-1686. In Mensen en Achtergronden, Studies nitgegeven ter gelegenheid van de tachtigste jaardag van de schrijver, edited by Johannes Gerard van Dillen, pp. 336-84. Groningen: J.B. Wolters.

-1970. Van Rijkdom en Regenten; handboek tot de economische en sociale geschiedenis van Nederland tijdens de Republiek. The Hague: Martinus Nijhoff.

Zappey, Wilhelmus M. 1982. Porselein en zilvergeld in weesp. Hollandse Studiën 12: 167-218. 